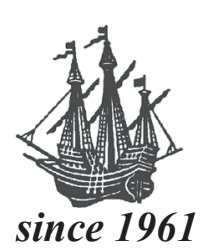

Baltica

BALTICA Volume 34 Number 2 December 2021: 174-184

https://doi.org/10.5200/baltica.2021.2.4

\title{
Phytoplankton of the transboundary River Viliya (Neris): community structure and toxic cyanobacterial blooms
}

\author{
Boris Adamovich*, Tamara Mikheeva, Ekaterina Sorokovikova, Olga Belykh, Ričardas \\ Paškauskas, Anton Kuzmin, Galina Fedorova, Hanna Zhukava, Jüratė Karosienė
}

\begin{abstract}
Adamovich, B., Mikheeva, T., Sorokovikova, E., Belykh, O., Paškauskas, R., Kuzmin, A., Fedorova, G., Zhukava, H., Karosiene, J. 2021. Phytoplankton of the transboundary River Viliya (Neris): community structure and toxic cyanobacte-
\end{abstract} rial blooms. Baltica, 34 (2), 174-184. Vilnius. ISSN 1648-858X.

Manuscript submitted 15 May 2020 / Accepted 14 October 2021 / Available online 20 November 2021

(C) Baltica 2021

\begin{abstract}
The 2011-2012 data on the hydrochemical mode of the transboundary River Viliya (Neris) and two of its tributaries in the territory of the Republic of Belarus and on structure of the phytoplankton community therein are presented. High phytoplankton biomass was determined in the summer period. For the first time, the presence of microcystin synthase genes (mcyE) was detected in the River Viliya (Neris), and four variants of microcystins were determined employing the MALDI-TOF method. Similarities in the species composition (including toxic species) of cyanobacteria from the River Viliya (Neris) and from the Curonian Lagoon of the Baltic Sea were noted. It can be assumed that the phytoplankton community structure of rivers can influence algal community formation in the downstream areas as well as in the coastal estuarine lagoons that eventually receive water from these rivers.
\end{abstract}

Keywords: biomass; cyanobacteria species composition; toxic species; microcystins

Boris Adamovich*(belaqualab@gmail.com),Tamara Mikheeva(mikheyeva@tut.by), Hanna Zhukava (hannazhukava@gmail.com), Belarusian State University, Nezavisimosti Ave 4, Minsk BY-220030, Republic of Belarus; Ekaterina Sorokovikova(kati_sor@mail.ru),OlgaBelykh (belykh@lin.irk.ru),Anton Kuzmin (kuzmin2000av@gmail.com), Galina Fedorova (fgalina@mail.ru), Limnological Institute of Siberian Branch of the Russian Academy of Sciences, Ulan-Batorskaya Str. 3, Irkutsk RU-664033, Russia; Ričardas Paškauskas (ricardas.paskauskas@gamtc.lt), Jūratè Karosiene (jurate.karosiene.gl@gmail.com), Nature Research Centre, Akademijos Str. 2, Vilnius LT-08412, Lithuania

*Corresponding author

\section{INTRODUCTION}

The Baltic Sea, the only inland sea that is entirely in Europe, is one of the largest brackish-water basins in the world. The combination of a large catchment area, a small volume of water with limited exchange and high human population density on the shores makes the Baltic Sea extremely sensitive to nutrient enrichment (HELCOM 2009). As a result, eutrophication is the major problem in the Baltic Sea. Since the 1900s, the oligotrophic clear-water environment in the Baltic Sea has turned into the eutrophic marine environment. About $75 \%$ of the nitrogen load and at least $95 \%$ of the phosphorus load enter the Bal- tic Sea via rivers or as direct waterborne discharges (HELCOM 2007). However, rivers bring macronutrients not only from the drainage basin, but also from the biological communities along their entire length, which, in accordance with the principles of the river continuum (Vannote et al. 1980; Lampert, Sommer 2007), can contribute to the species diversity of the downstream reaches, including the Baltic Sea itself. The influence of river flow is especially evident in semi-enclosed costal water bodies with slow water-exchange such as the Curonian Lagoon (Vybernaite-Lubiene et al. 2018). It is not surprising that recurrent harmful cyanobacterial blooms are observed regularly in the Lagoon, including those of the 
potentially toxic cyanobacteria (Schmidt-Ries 1940; Krevs et al. 2007; Paldavičienè et al. 2009; Belykh et al. 2013; Bresciani et al. 2012, 2014; Šulčius et al. 2015; Bartoli et al. 2018). However, toxic blooms can be formed not only in the Lagoon itself, but also in the rivers carrying their water into the Lagoon. The river basin approach to the ecological state monitoring and reduction of nutrient load in river drainage basins (EC - European Community 2000) also highlights the relevance of studying transboundary rivers.

The River Viliya (Neris) belongs to the Baltic Sea basin and is the largest tributary of the Neman River, which, in turn, is one of the sources of the Baltic Sea pollution (HELCOM 2013). In addition, the fact that the Viliya (Neris) River is the only waterway in the territory of Belarus used by Salmonidae for spawning (Pliuta et al. 2007) heightens the need for its water quality monitoring. Finally, the River Viliya (Neris) is the main source of water for the cooling system and a receiver of technical water from the Belarusian $\mathrm{Nu}-$ clear Power Plant (Validation of investments... 2010), which is being built in close vicinity of the Lithuanian border and its capital Vilnius. The potential influx of significant amounts of major nutrients (especially, of mineral phosphorus) with wastewater from the Belarusian Nuclear Power Plant together with thermal pollution may further aggravate the trophic state of the river (Validation of investments... 2010).
In this paper we present data on the phytoplankton community of the River Viliya (Neris), which were collected throughout the 2011-2012 vegetation seasons, well before the start of significantly increased industrialization and excessive urbanization of the river.

\section{MATERIALS AND METHODS}

\section{Study area}

The study was conducted in the River Viliya (Neris) and in two tributaries: the Smerdiya and Usha Rivers. Both of these tributaries have fish farms located on their watershed (Fig. 1). To study the ecological state of the River Viliya (Neris), five stations were selected (Table 1) in the River Viliya (Neris), and two additional stations (6 and 7) in tributaries of the River Viliya, the Smerdiya and Usha Rivers.

The River Viliya (Lithuanian name Neris) is a right-bank tributary of the River Neman in Belarus and Lithuania. Its length is $498 \mathrm{~km}$, including $264 \mathrm{~km}$ in Belarus. The river is characterized by intense floods (which accounts for $45 \%$ of the annual flow) in spring, by mostly standing water during the summer low water period, which is annually disrupted by rain floods, and by stable water during the winter low water period. The Vileyski Reservoir was built on the

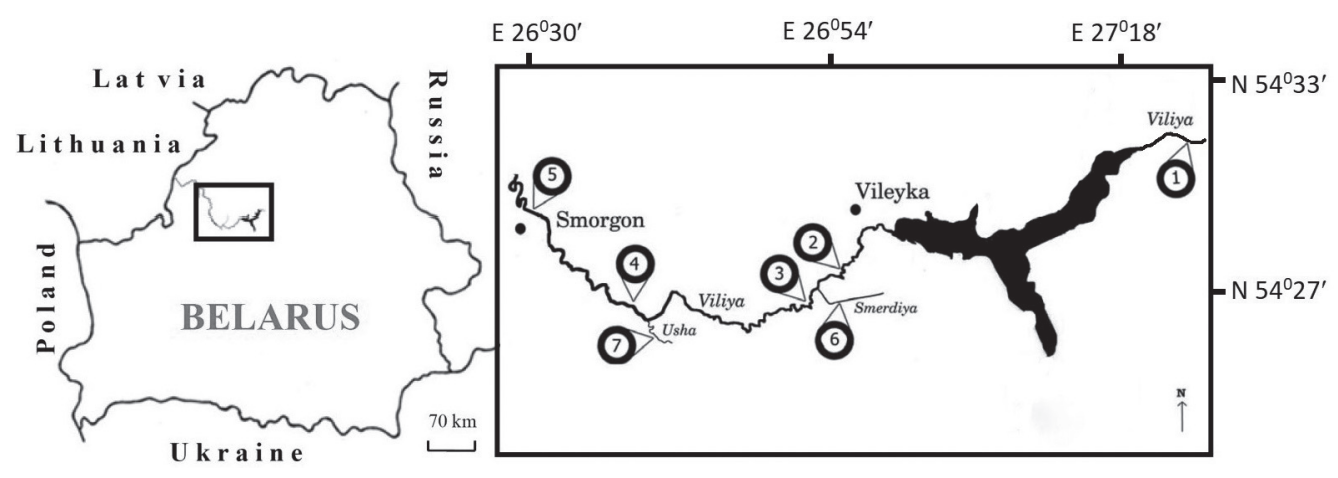

Fig. 1 Location of sampling stations within the Republic of Belarus

Table 1 The selected stations in the River Viliya (Neris)

\begin{tabular}{|c|c|c|l|c|}
\hline Stations & Latitude & Longitude & \multicolumn{1}{|c|}{ Sampling location } & Annual river discharge $\left(m^{3} \mathrm{~s}^{-1}\right)$ \\
\hline 1 & $54^{\circ} 33^{\prime} 50.31^{\prime \prime} \mathrm{N}$ & $27^{\circ} 23^{\prime} 44.11^{\prime \prime} \mathrm{E}$ & River Viliya (Neris) near village Steshitsa & $2.9^{*}$ \\
\hline 2 & $54^{\circ} 27^{\prime} 15.01^{\prime \prime} \mathrm{N}$ & $26^{\circ} 54^{\prime} 3.49^{\prime \prime} \mathrm{E}$ & River Viliya (Neris) near village Glinnoe \\
\hline 3 & $54^{\circ} 25^{\prime} 42.49^{\prime \prime} \mathrm{N}$ & $26^{\circ} 50^{\prime} 54.57^{\prime \prime} \mathrm{E}$ & $\begin{array}{l}\text { River Viliya (Neris) downstream from the inflow of } \\
\text { the River Smerdiya }\end{array}$ & $28.1^{*}$ \\
\hline 4 & $54^{\circ} 25^{\prime} 23.11^{\prime \prime} \mathrm{N}$ & $26^{\circ} 35^{\prime} 21.11^{\prime \prime} \mathrm{E}$ & $\begin{array}{l}\text { River Viliya (Neris) downstream from the inflow of } \\
\text { the River Usha }\end{array}$ & $28.1^{*}$ \\
\hline 5 & $54^{\circ} 31^{\prime} 54.48^{\prime \prime} \mathrm{N}$ & $26^{\circ} 23^{\prime} 53.82^{\prime \prime} \mathrm{E}$ & River Viliya (Neris) downstream from Smorgon city & $79.6^{*}$ \\
\hline 6 & $54^{\circ} 25^{\prime} 59.89^{\prime \prime} \mathrm{N}$ & $26^{\circ} 51^{\prime} 3.98^{\prime \prime} \mathrm{E}$ & $\begin{array}{l}\text { River Smerdiya upstream from the inflow to the } \\
\text { River Viliya (Neris) } \\
\text { River Usha upstream from the inflow to the River } \\
\text { Viliya (Neris) }\end{array}$ & $0.5^{* *}$ \\
\hline 7 & $54^{\circ} 24^{\prime} 55.27^{\prime \prime} \mathrm{N}$ & $26^{\circ} 36^{\prime} 24.72^{\prime \prime} \mathrm{E}$ & $6.01^{*}$ \\
\hline
\end{tabular}

*According to Pashkou et al. (2007)

**According to the data from the Fish Industry Institute of Belarus. 
River $70 \mathrm{~km}$ downstream of Minsk in 1973-1975. After the Reservoir had been put into operation, the level and flow regime below the dam in Belarus became dependent on the operation of the Reservoir. The catchment area of the River Viliya is 25.1 thousand $\mathrm{km}^{2}$ (including 11 thousand $\mathrm{km}^{2}$ in Belarus); $32 \%$ of which is covered with forest, and there are many lakes on the right bank of the River. The Viliya River is the power source of the Vileyka-Minsk water system (Pashkou et al. 2007). The River is to become the main source and receiver of technical water from the Belarusian Nuclear Power Plant (Validation of investments... 2010).

The River Smerdiya (length $14 \mathrm{~km}$, catchment area $31 \mathrm{~km}^{2}$ ) and the River Usha (length $75 \mathrm{~km}$, catchment area $780 \mathrm{~km}^{2}$ ) are left tributaries of the River Viliya (Neris). In the drainage basin of the River Smerdiya, there is a fish farm Vileyka with ponds (193 ha area). The fish farm Gritsevo, with ponds covering an area of 149 ha, is located in the River Usha drainage basin.

\section{Field sampling and methods}

Samples for phytoplankton and water chemistry analysis were collected in April, July and September 2011 and in May, July and November 2012 monthly from the surface water layer $(0-1 \mathrm{~m})$ at each station using a tube sampler (volume $3 \mathrm{~L}$ ). A total of 42 samples were collected for each parameter (phytoplankton and water chemistry).

Water quality parameters were analysed following the methods described in (Semenov 1977; Wetzel, Likens 2003). Mineral nitrogen was determined as the sum of ammonium, nitrate and nitrite nitrogen. Mineral forms of nitrogen and phosphate phosphorus were analysed employing the photo-colorimetric method. The content of organic matter was assessed by potassium permanganate oxidation. Dissolved oxygen was measured using the standard Winkler method. Water temperature was measured using a mercury deep-water thermometer with a scale resolution of $0.1^{\circ} \mathrm{C}$.

Water samples $(0.5 \mathrm{~L})$ for phytoplankton analysis were fixed with Utermöhl's solution (Mikheyeva 1989). Utermöhl's technique is widely accepted as the best method for phytoplankton studies (Taylor et al. 1986). The samples were sedimented in total darkness at least for one week. Then the samples were concentrated up to $100-150 \mathrm{ml}$ by pouring off all excess water using a thin silicon or rubber siphon covered with a two-layer $77 \mu \mathrm{m}$-size mesh plankton net. The resulting concentrate was poured into plankton bottles and allowed no less than 2-3 days to settle. Then the extra water was drawn out using a medical syringe with a thin vinyl tubule at its end. Finally, the actual sample volume was $15-30 \mathrm{ml}$ depending on the sediment thickness. The light Zeiss Axiolab microscope was used to analyse phytoplankton samples. A Fuchs-Rosenthal chamber with a volume of $3.2 \mathrm{~mm}^{3}$ was used to count small $(<100 \mu \mathrm{m})$ phytoplankton organisms. The larger species such as Ceratium, Asterionella, Melosira, Aulacoseira, Fragilaria, Microcystis, Coelosphaerium, Anabaena and some other were counted using a $1 \mathrm{ml}$ chamber while large colonial organisms were counted using the Bogorov one. Phytoplankton biomass was calculated using Kiselev's method of true volumes (Kiselev 1969). According to this technique, volumes were calculated for each species by applying a solid geometric shape (ellipsoid, sphere, rod, cone, etc.) most closely matching the shape of the cells or organisms (Hillebrand et al. 1999; Mikheyeva 1999). The total biomass of phytoplankton was calculated by summing up the calculated weights of each organism.

Samples for molecular analysis were collected in May and July 2012 using an Apstein net and were fixed with ethyl alcohol ( $80 \%$ final concentration). The samples were used for determination of $m c y \mathrm{E}$ gene responsible for the synthesis of microcystins (MCs). DNA from the samples was extracted using "Genomic DNA Purification Kit'" (Thermo Scientific, USA). Amplification was done using primers hepF and hepR (Jungblut, Neilan 2006). The use of AMT domain as the target genetic marker showed its effectiveness in identifying toxigenic cyanobacteria (Belykh et al. 2011; Mikheyeva et al. 2012). DNA of a MCs-producing cyanobacterium strain Microcystis aeruginosa CALU 972 was used as a control. DNA isolation was performed using the phenol-chloroform method (Belykh et al. 2011). Polymerase chain reaction (PCR), cloning and sequencing were performed as described in the article by Belykh et al. (2011). The unique nucleotide sequences were deposited in GenBank under numbers KC900837-KC900842, amino acid - under numbers AGO06701-AGO06706.

Sequences of $m c y \mathrm{E}$ gene were edited using the BioEdit (v. 7.0.9) (Hall 1999). Search for immediate neighbours was conducted using BLAST analysis (E-value threshold-1e-6). The phylogenetic tree was built using the MEGA 7 software and applying the neighbour joining method (NJ) (Kumar et al. 2016). The tree of amino acid sequences was constructed using the maximum likelihood method and bootstrap analysis.

Samples for MCs analysis were collected in July 2012 and prepared for analysis as described in the article by Belykh et al. (2011) and Mikheyeva et al. (2012). The detection and identification of MCs was performed from field phytoplankton samples collected on GF/F filters by the MALDI-TOF method (matrix activated laser desorption/ionization); $\alpha$-Cyano4-hydroxycinnamic acid was used as a matrix. MCs 
were detected using the mode of the positive ions registration (the working wavelength of the laser is $355 \mathrm{~nm}$ ). The mass range is $500-3500 \mathrm{Da}$.

\section{RESULTS}

\section{Water chemistry}

No clear trends were found in the spatial dynamics of nitrogen mineral forms. The observed changes (Table 2) were likely caused by local sources of pollution along the river gradient. Almost at all sites, nitrogen concentrations were found to be higher in spring than in summer and autumn, when biological communities of the river are most actively involved in selfpurification processes. Comparison of total mineral nitrogen concentrations at the river station No 1 with its content at other stations indicated that the change in mineral nitrogen downstream was comparatively small and did not exceed $30 \%$. At individual river stations (i.e. No 2), the seasonal mean values exceeded $0.8 \mathrm{mg} \mathrm{L}^{-1}$, and in spring exceeded $1.8 \mathrm{mg} \mathrm{L}^{-1}$.

The dynamics of seasonal mean values (Table 2) indicated a weak trend of mineral phosphorus accumulation downstream. Low concentrations of mineral phosphorus at the river station No 2 located below the Reservoir can be explained by the fact that it is intensively consumed by aquatic organisms and is affected by sedimentation in the Reservoir.
During the study period, the content of organic matter remained almost unchanged throughout the river section.

\section{Phytoplankton composition and biomass}

A total of 106 taxa of the species or lower rank were identified in the phytoplankton of the River Viliya (Neris), and additional 59 taxa were found in its two tributaries (Table 3). The number of taxa at different cross-sections varied slightly from 46 to 52. In the River Viliya (Neris), the largest number of species (38 taxa) belonged to Chlorophyta. Second in numbers were diatoms (22 taxa), and third were cyanobacteria (22 taxa) (Table 3). The most common genera of diatoms found at all sampling stations were Asterionella, Cocconeis, Cyclotella, Navicula, Nitzschia, Pinnularia, Stephanodiscus, Synedra; Chlorophyta - Ankistrodesmus, Chlorella, Didymocystis, Micractinium, Oocystis, Pediastrum, Scenedesmus, Chlamydomonas, and Phacotus. The most common genera of Chrysophyceae were Chromulina, Kephyrion, Ochromonas, the most common of Cryptophyta were Cryptomonas, Rhodomonas, of Cyanobacteria Dolichospermum, Aphanizomenon, Gomphosphaeria, Lyngbya, Microcystis, Planktothrix, Pseudanabaena; and the most common genus of Euglenophyceae was Trachelomonas.

The phytoplankton biomass of the River Viliya (Neris) varied among the river sections studied and

Table 2 Environmental factors at different river stations of the River Viliya (Neris) and its tributaries (average $(n=6) \pm$ SD for spring, summer and autumn 2011-2012)

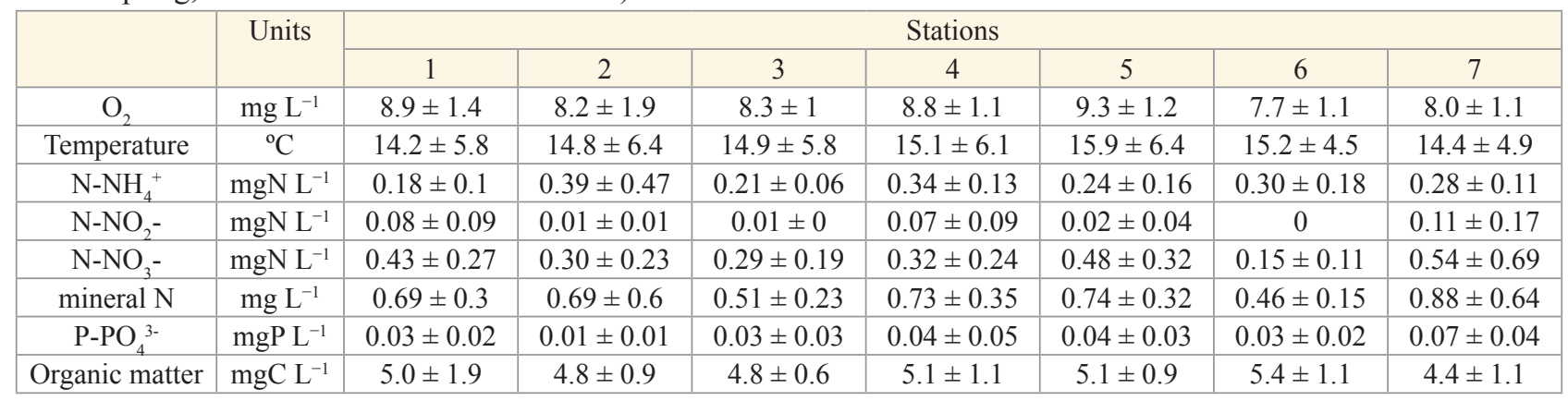

Table 3 The number of the phytoplankton taxa (Chlor - Chlorophyta, Chrys - Chrysophyceae, Crypt - Cryptophyta, Cyan - Cyanobacteria, Diat - diatom algae including Bacillariophyceae, Fragilariophyceae and Coscinodiscophyceae, Din - Dinophyta, Eugl - Euglenophyceae, Xant - Xanthophyceae) at the sampling stations

\begin{tabular}{|c|c|c|c|c|c|c|c|c|c|}
\hline \multirow{2}{*}{ Taxonomic groups } & \multicolumn{7}{|c|}{ Stations } & \multirow{2}{*}{$\begin{array}{l}\text { A total of taxa in } \\
\text { River Viliya (Neris) }\end{array}$} & \multirow{2}{*}{$\begin{array}{l}\text { A total of taxa } \\
\text { in tributaries }\end{array}$} \\
\hline & 1 & 2 & 3 & 4 & 5 & 6 & 7 & & \\
\hline Diat & 13 & 14 & 16 & 15 & 18 & 10 & 17 & 24 & 19 \\
\hline Chlor & 22 & 14 & 15 & 17 & 12 & 13 & 8 & 38 & 17 \\
\hline Chrys & 2 & 1 & 3 & 3 & 4 & 2 & 4 & 9 & 5 \\
\hline Crypt & 4 & 3 & 2 & 4 & 2 & 3 & 2 & 7 & 3 \\
\hline Cyan & 8 & 12 & 12 & 7 & 10 & 5 & 3 & 22 & 7 \\
\hline Din & 1 & - & - & - & - & - & - & 1 & - \\
\hline Eugl & 2 & 2 & 2 & 2 & 1 & 5 & 4 & 4 & 8 \\
\hline Xant & - & - & 1 & - & - & - & - & 1 & - \\
\hline Total & 52 & 46 & 51 & 48 & 47 & 38 & 38 & 106 & 59 \\
\hline
\end{tabular}


seasons (Fig. 2). The smallest seasonal variations in biomass, indicative of the relative phytoplankton community stability, were observed at the river station No 1 located upstream of the Reservoir. During both study years, a slight increase in biomass was noticeable at the station No 2 downstream of the Vileyka Reservoir. The biomass decreased slightly towards the river station No 4 and increased again downstream of the town of Smorgon at the station No 5, where the biomass was approximately twice higher than that at the river station No 1 .

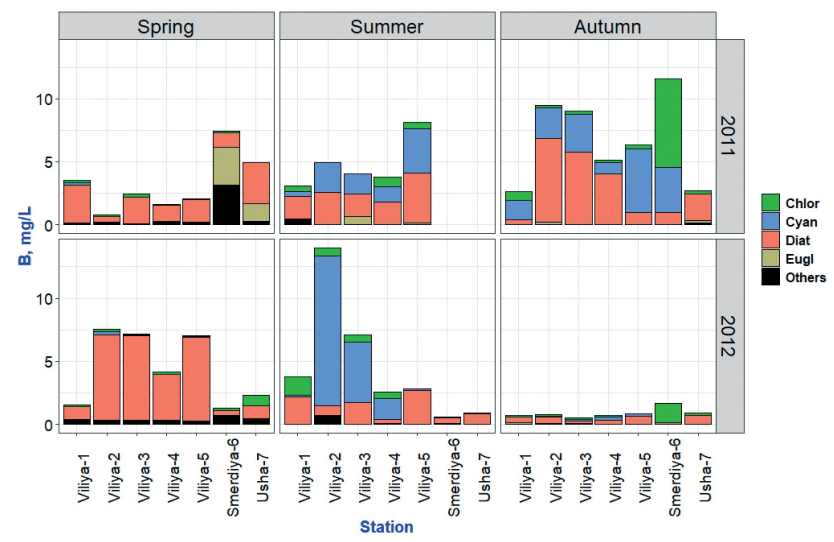

Fig. 2 Changes in phytoplankton composition and biomass at sampling stations in the River Viliya (Neris) and its tributaries in 2011 and 2012 (Chlor - Chlorophyta, Cyan Cyanobacteria, Diat - diatom algae including Bacillariophyceae, Fragilariophyceae and Coscinodiscophyceae, Eugl - Euglenophyceae, Others - algae including Dinophyta, Chrysophyceae, Cryptophyta and Xanthophyceae)

The two-year phytoplankton biomass is quite different, especially in spring and autumn seasons (Fig. 2), which can be explained by a considerable difference in temperature at the time of sampling in 2011 and 2012. The mean water temperatures at the time of sampling in spring and autumn in 2011 were $12.4 \mathrm{C}^{0}$ and $14.3 \mathrm{C}^{0}$ accordingly, while respective temperatures in 2012 were $16.3 \mathrm{C}^{0}$ and $5.6 \mathrm{C}^{0}$. The total phytoplankton biomass significantly correlated with water temperature (Spearman correlation coefficient $=0.60 ; p=0.002$ ).

Diatoms that are typical inhabitants of lotic systems, were dominant at all river stations throughout the growth season and especially during spring (accounting for up to $94.3 \%$ of the phytoplankton biomass in spring 2012 at the station No 5) (Fig. 2). Cyanobacteria, which are typical indicators of a nutrient load in a watershed, also made a significant contribution to the phytoplankton biomass in summer and autumn (up to $84.4 \%$ and $80.4 \%$, accordingly), indicating a high anthropogenic load in the River Viliya (Neris). In summer, the biomass of cyanobacteria at the station 2 downstream of the Vileyski Reservoir increased 3.7-fold in 2011, and 24.4-fold in 2012. Cyanobacteria became dominant downstream of the Vileyski Reservoir at the stations No 2 and No 3, and downstream of the town of Smorgon at the station No 5.

The biomass of phytoplankton fluctuated significantly in the tributaries among years (Fig. 2). However, the impact of tributaries on river plankton community was negligible due to the relatively small volume of water in the tributaries as compared to that in the River Viliya (Neris). The flow of the River Smediya to the River Viliya (Neris) actually stops in summer. During the study period, the biomass of phytoplankton in the River Usha was lower than in the River Viliya (Neris), indicating that this inflow water can only reduce the phytoplankton biomass in the main river bed.

\section{Potentially toxic species of Cyanobacteria}

The high trophic state of the River Viliya (Neris) is indicated by the high phytoplankton biomass that reached $7.5 \mathrm{mg} \mathrm{L}^{-1}$ as early as mid-May. However, no significant growth of cyanobacteria was recorded in that period and the cyanobacteria biomass reached up to $0.23 \mathrm{mg} \mathrm{L}^{-1}$. In July, the phytoplankton biomass

Table 4 Composition (\% in total biomass of phytoplankton) of cyanobacteria in the River Viliya (Neris) in May and July 2012

\begin{tabular}{lcc}
\hline \multicolumn{1}{c}{ Species } & \multicolumn{2}{c}{ Date } \\
\cline { 2 - 3 } & 11 May 2012 & 06 July 2012 \\
\hline Aphanizomenon flos-aquae (L.) Ralfs* & - & 69.88 \\
Aphanothece clathrata W. et G.S. West & 0.31 & 4.33 \\
Chroococcus minutus (Kützing) Nägeli & 0.5 & - \\
Cyanodictyon planctonicum Meyer & 0.12 & - \\
Dolichospermum (Ralfs ex Bornet \& Flahault) P. Wacklin, L.Hoffmann \& J.Komárek sp.* & - & 4.14 \\
Gloeocapsa (Kütz.) Hollerb. sp. & - & 0.69 \\
Microcystis viridis (A.Braun) Lemmermann* & 1.07 & 4.39 \\
Planktolyngbya limnetica (Lemmermann) Komárková-Legnerová \& Cronberg* & 0.07 & 0.09 \\
Planktothrix agardhii (Gomont) Anagnostidis \& Komárek* & 1.0 & - \\
Synechocystis Näg. sp. & - & 1.55 \\
\hline
\end{tabular}

*Species considered as potential toxin producers according to Bernard et al. (2017). 
was still increasing (up to $13.98 \mathrm{mg} \mathrm{L}^{-1}$ ), and cyanobacteria became dominant $(85 \%$ of phytoplankton biomass). The biomass of potentially toxic cyanobacteria was $10.97 \mathrm{mg} \mathrm{L}^{-1}$ and comprised $78.5 \%$ of the total phytoplankton biomass. Changes in the biomass of cyanobacteria in the River Viliya (Neris) significantly correlated with water temperature (Spearman correlation coefficient $=0.43 ; p=0.012$ ).

At that time, 10 representatives of cyanobacteria were recorded (Table 4). Five of the species, accord- ing to Bernard et al. (2017), are considered to be potential toxin producers. Aphanizomenon flos-aquae dominated phytoplankton in summer accounting for up to $73.1 \%$ of the total biomass (Table 4).

Thirty cloned sequences were obtained from the samples collected in July 2012 from the River Viliya (Neris) at the station No 2, six of which represented different genotypes bearing the $99 \%$ similarity to one another (Fig. 3). The length of the nucleotide sequences was $470 \mathrm{bp}$.

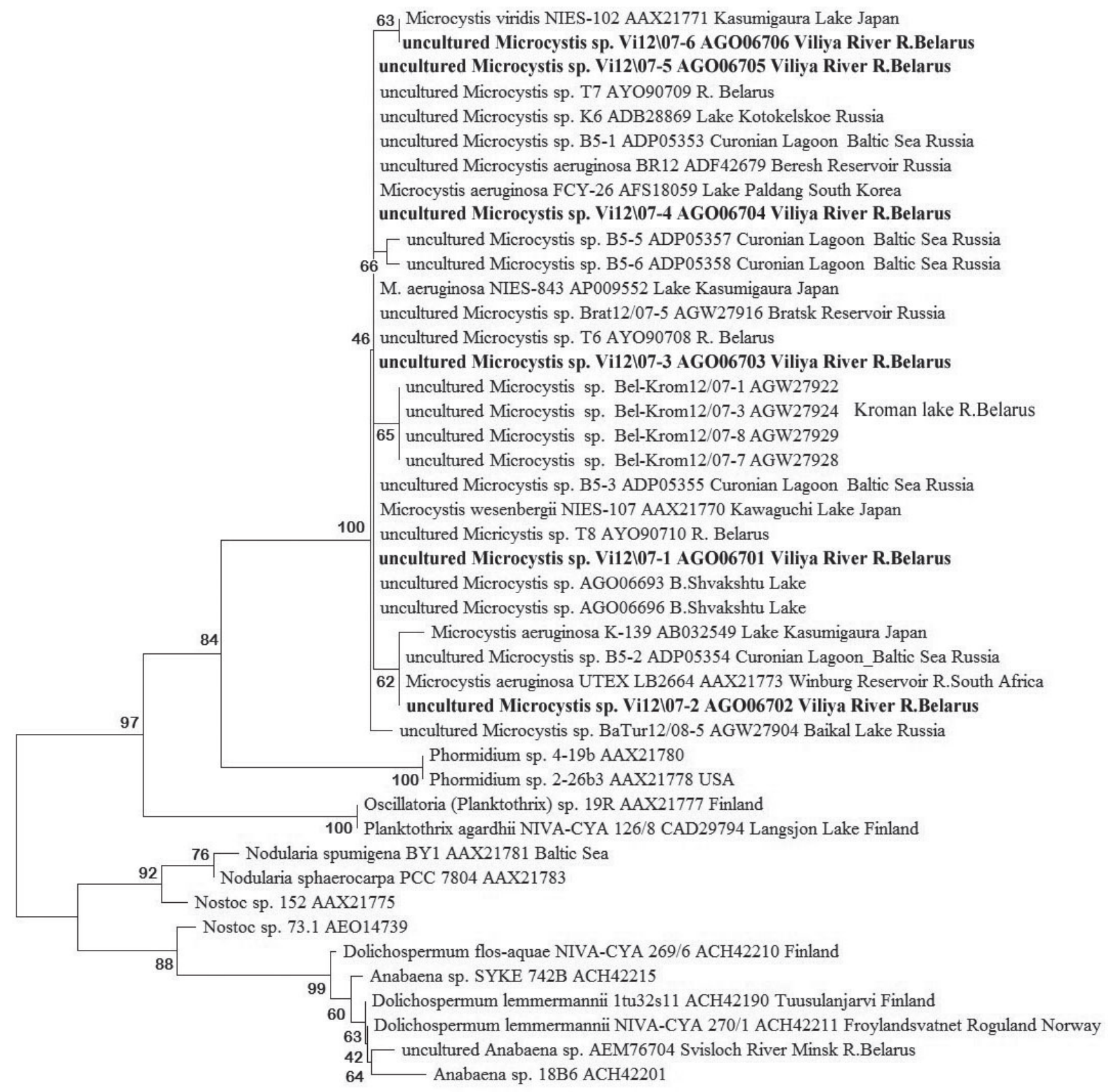

0,020

Fig. 3 The maximum-likelihood tree based on partial amino acid sequences of AMT domain. The sequences obtained in this study are marked in bold. Bootstrap values $>50$ expressed as percentage of 1000 maximumlikelihood bootstrap replicates are given at the nodes. Scale bar corresponds to 2 substitutions per 100 amino acids 


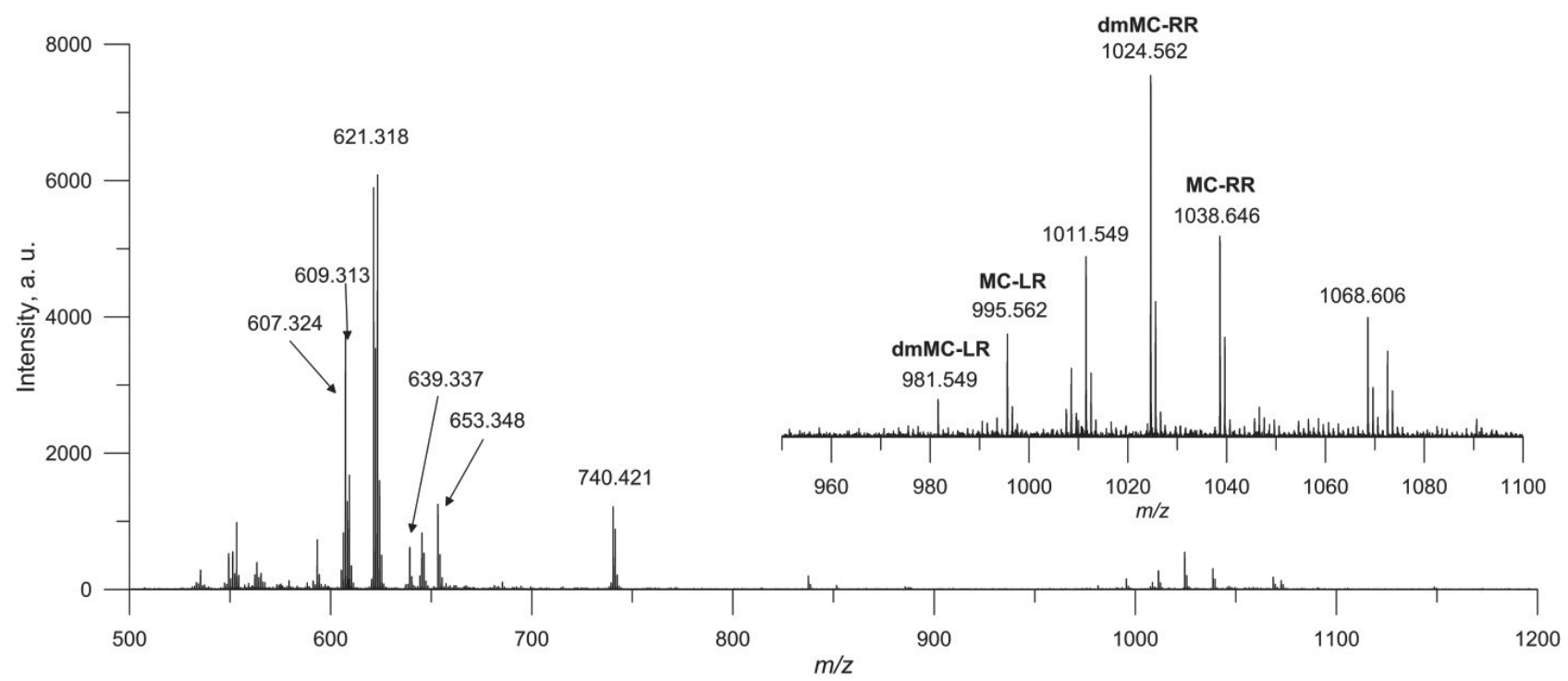

Fig. 4 The MALDI-TOF mass spectrum of the samples collected from the River Viliya (Neris) on 6 July 2012

By performing MALDI-TOF analysis, we obtained peaks of $[\mathrm{M}+\mathrm{H}]^{+}$molecular ions (Fig. 4) and compared their characteristic ratios with literature data. Two most common microcystin variants, MC-LR and MC-RR, as well as the less common variant MC-WR, were detected in the mass spectrum. The molecular ion $[\mathrm{M}+\mathrm{H}]^{+}$with the mass value of $\mathrm{m} / \mathrm{z} 981.599$ was found to correspond to the demethylated MC-LR microcystin variant (dmMC-LR).

\section{DISCUSSION}

The River Viliya (Neris) is supposed to be exposed to a significant "enrichment" with mineral nitrogen throughout most of its length. Previously, nitrogen was shown to be one of the main nutrients contributing to water eutrophication (Rekolainen et al. 2005; Schindler 2006). The assessment of the River Viliya (Neris) water quality based on the concentration of mineral nitrogen showed that the station No 3 was least polluted. Taking into consideration the fact that the station No 5 was located downstream of the Smorgon town, which is not far from the border with the Republic of Lithuania, we assumed that the quality of the River Viliya (Neris) water flowing from the territory of the Republic of Belarus to the neighbouring country is similar to that of the water in the river stretch from the Vileyski Reservoir downstream. The analysis of phosphorus dynamics in water is complicated due to the high rate of mineral phosphorus turnover in the ecosystem. A small accumulation of mineral phosphorus at the station No 2 demonstrated an incomplete uptake of phosphorus by primary producers.

As environmental changes cause rapid structural and functional reorganization of aquatic communities, the biological assessment of water quality provides dynamic evaluation. Disruption of homeostasis in a water body can lead to scenarios, where aquatic organisms themselves become additional contamination. And even if the input of chemical pollutants into the water body discontinues, the water body may already shift to a different trophic level, and it will take a long time and additional effort to restore the previous state of the water body. Phytoplankton community is one of the most important components in aquatic monitoring as it is mainly its abundance and structure that determine the trophic status of water bodies and water quality therein (Wetzel 2001; Spänhoff et al. 2012; Bilous et al. 2014).

The taxonomic composition of phytoplankton in the River Viliya (Neris) described in this study is typical of other rivers of Belarus. In recent decades, large river systems of Belarus experienced increased pressure from anthropogenic activities, as a result of which the species adapted to high levels of organic enrichment and nutrients became dominant in phytoplankton communities. According to the findings of several studies (Astapovich 1996; Prosyanik et al. 1996; Astapovich et al.1998; Adamovich et al. 2009), the only large river of Belarus with the prevalence of diatoms in phytoplankton is the Zapadnaya Dvina, which is much less exposed to the anthropogenic load than other major rivers (Astapovich et al.1998; Adamovich et al. 2012).

The effect of the phytoplankton input from two tributaries on the River Viliya (Neris) water quality was found to be weak, just like that of the phytoplankton input in autumn, when the discharge of water from fish farms is the largest. Based on quantitative indicators, and the dominance of cyanobacteria in phytoplankton determined in this study, the trophic status of the River Viliya (Neris) was higher than that of other major rivers of Belarus. The dominance of cyanobacteria and the presence of toxic species in phytoplankton are characteristic features of eutrophication (O'Neil et al. 2012; Pearl 2016). Our study is the first one to reveal the presence of 
toxigenic cyanobacteria of the genus Microcystis, which possess microcystins synthesis genes, in water of the River Viliya (Neris). Four variants of microcystins (MCLR, dmMC-LR, MC-RR and MC-WR) were identified using the MALDI-TOF method. MC-LR and MC-RR are the most common variants of them in blooms dominated by Microcystis spp. and Planktothrix agardhii in the Curonian Lagoon of the Baltic Sea (Paldavičiene et al. 2009; Ehzova et al. 2012; Šulčius et al. 2015). Cleavage of the methyl group is possible in three different amino acid residues of the microcystin molecule, providing three options: [D-Asp ${ }^{3}$ MC-LR, [Dha7] MCLR or [DMAdda5] MC-LR (Sivonen, Jones 1999). Accurate identification of the demethylated version was impossible due to its low concentration in the sample. According to BLAST analysis, uncultivated immediate relatives (99\% similarity) of nucleotide sequences from the River Viliya (Neris) are the sequences of the AMT domain of cyanobacteria from other water bodies, including those we identified in Lakes Baikal and Kotokelskoye in Eastern Siberia (Russia) (Gaevsky et al. 2011; Belykh et al. 2011), the Curonian Lagoon of the Baltic Sea (Belykh et al. 2013), in Lakes Bolshie Shvakshty and Kroman (Belarus) (Mikheyeva et al. 2018a, b), as well as in Lake Doirani (Greece) (Gkelis, Zaoutsos 2014). The cultivated species were found to show the greatest similarity (99\%) with strains of $M$. aeruginosa K-139, M. viridis NIES-102, M. aeruginosa NIES-843, M. aeruginosa FCY-26, isolated during toxic cyanobacteria blooms in lakes of Japan (Nishizawa et al. 2000; Rantala et al. 2004; Kaneko et al. 2007) and Korea (Rhee et al. 2012).

On the tree, amino acid sequences of aminotransferase form stable clades corresponding to the species of cyanobacteria (Microcystis, Dolichospermum, Planktothrix, Nostoc, Nodularia, Phormidium) capable of producing MCs. All amino acid sequences of cyanobacteria from the River Viliya are included into the clade of the Microcystis species (boot-strep support of $100 \%$ ) (Fig. 3). Inside the clade, the clone Microcystis sp. Vi12/07-2 is grouped with strains of M. aeruginosa K-139 from Lake Kasumigaura (Japan), M. aeruginosa UTEXLB 2664 from South Africa and the uncultivated sequence Microcystis sp. B5-2 from the Curonian Lagoon of the Baltic Sea. The sequence Microcystis sp. Vi12/07-6 forms a cluster with an isolate of $M$. viridis NIES-102 from Lake Kasumigaura. Four sequences from the River Viliya (Neris) form separate lines inside the clade as well as some sequences from the Curonian Lagoon and Lake Bolshie Shvakshty (Belarus). Separate clusters are formed by sequences from Lake Kroman (Belarus) and two sequences from the Curonian Lagoon.

Ecological studies of rivers are primarily based on several fundamental concepts such as river continuum and flood pulse concepts (Vannote et al. 1980; Dokulil
2014). The alternative point of view considers rivers as "neutral pipes" that transport organic matter to the sea (Cole et al. 2007). Based on their biogeochemical and microbiological data, Gladyshev et al. (2015) concluded that a river ecosystem can complexly combine features of a river mosaic, river continuum, and those of a "neutral pipe". It can be assumed that the phytoplankton composition in rivers can be influenced by the algal community of their tributaries, and, in turn, can affect the phytoplankton community composition in the marine lagoons receiving water from these rivers (Lange, Makushenko 2018). The molecular genetic identification of the toxic representatives of Microcystis species in the River Viliya revealed their similarity with the Microcystis strains that occurred in the Curonian Lagoon (Belykh et al. 2013; Ehzova et al. 2012; Lange 2013). Moreover, the cyanobacterium Aphanizomenon flos-aquae, which dominates the River Viliya phytoplankton in summer, is also the main dominant species in the Curonian Lagoon of the Baltic Sea (Belykh et al. 2013), which receives waters from the River Neman and its major tributary, the River Viliya. Although A. flos-aquae is considered to be a toxin producer (Bernard et al. 2017), its strains from the Curonian Lagoon have been shown to be unable to produce toxins (Ščius et al. 2015). Thus, it is quite probable that the cyanobacterial strains causing blooms in the Curonian Lagoon historically originated in the large tributaries of the River Neman. In May-October 2013-2017, the mineral nitrogen content in the Curonian Lagoon was $78.3 \mathrm{mg} \mathrm{L}^{-1}$ (Malfanov et al. 2017), which was very similar to our measurements of nitrogen at the station No 5 (Table 2). The content of mineral phosphorus in the Curonian Lagoon was somewhat lower and ranged from 4 to $9 \mu \mathrm{g} \mathrm{L}^{-1}$ (Malfanov et al. 2017). In 20072016, the concentration of mineral phosphorus in the Curonian Lagoon ranged from 5 to $30 \mu \mathrm{g} \mathrm{L}{ }^{-1}$ (Aleksandrov et al. 2018) and was similar to the concentrations we found in the Belarusian part of the River Viliya (Neris) during our research. Therefore, at some historical stage, changes in phytoplankton community in the main tributaries of the River Neman could have affected phytoplankton including cyanobacteria in the $\mathrm{Cu}$ ronian Lagoon. It should be noted that changes in the biomass of cyanobacteria in the River Viliya (Neris) significantly correlated with water temperature, one of the main factors promoting cyanobacterial growth. The potential influx of major nutrient elements (especially mineral phosphorus) with wastewater from the Belarusian Nuclear Power Plant in combination with thermal pollution may further aggravate the trophic status of the River (Validation of investments... 2010), and contribute to an increase in cyanobacteria proliferation causing toxic blooms. This, in turn, will produce additional load on the River Neman, one of the main sources of the Baltic Sea pollution (HELCOM 2013). 
Additional nutrient load can also directly affect the Curonian Lagoon of the Baltic Sea, which is already subjected to significant eutrophication (Belykh et al. 2013; Malfanov et al. 2017; Aleksandrov et al. 2018; Bartoli et al. 2018; Vybernaite-Lubiene et al. 2018). Phytoplankton monitoring, including toxic cyanobacteria, should be an essential part of biological monitoring in the River Neman and its major tributaries, such as the River Viliya (Neris).

\section{ACKNOWLEDGEMENTS}

This study was supported by the Russian Foundation for Basic Research (projects No. 3-a and No. 12-0490012_Bel_a), by the State Tasks No. 0345-2016-0003 and No. 0279-2021-0015 and by the Belarusian Republican Foundation for Fundamental Research (projects No. 512P-028 and No. Б20У-003). We are very thankful to the staff of the Republican Unitary Enterprise «Fish Industry Institute» for the provided assistance in field sampling and to Dr L. Burlakova for her valuable help in preparing and editing this manuscript. We thank two anonymous reviewers whose valuable comments greatly contributed to the manuscript improvement.

\section{REFERENCES}

Adamovich, B.V., Voronova, G.P., Kucko, L.A., Sennicova, V.D. 2009. Izmenenie urovnya razvitiya i struktury fitoplanktonnogo soobshchestva vdol' gradienta krupnoj ravninnoj reki, ispytyvayushchej sil'noe antropogennoe vozdejstvie [Change of the level of development and structure of the phytoplankton community along the gradient of a large flat river subjected to a strong anthropogenic impact]. Ekologiya morya [Sea Ecology] 78, 5-10. [In Russian].

Adamovich, B.V., Kutsko, L.A., Supranovich, V.V. 2012. Gidrohimicheskij i gidrobiologicheskij podhody k ocenke ekologicheskogo sostoyaniya krupnyh rek [Hydrochemical and hydrobiological approaches to the assessment of the ecological state of large rivers]. In: Zavodnik I.B. (ed.), Materialy VIII Mezhdunarodnoj nauchno-prakticheskoj konferencii "Aktual'nye problemy ekologii» [Proceedings of the VIII International Scientific and Practical Conference "Actual Problems of Ecology”]. Part 2. Grodno, 107-123. [In Russian].

Aleksandrov, S.V., Krek, A.V., Bubnova, E.S., Danchenkov, A.R. 2018. Eutrophication and effects of algal bloom in the south-western part of the Curonian Lagoon alongside the Curonian Spit (Russia). Baltica 31 (1), 1-12.

Astapovich, I.T. 1996. Kompleksnye issledovaniya gidroekologicheskogo rezhima reki Neman na uchastke respubliki Belarus' [Complex studies of the hydroecological regime of the Neman River in the area of the Republic of Belarus]. Voprosy rybnogo hozyastva Belarusi [Fish industry issues in Belarus] 14, 151-155. [In Russian].

Astapovich, I.T., Voronova, G.P., Kutsko, L.A., Zhukovs- kaya, T.I., Prosyanik, L.V., Gadlevskaya, N.N. 1998. Antropogennoe evtrofirovanie glavnyh rechnyh ekosistem Belarusi i ego vliyanie na kachestvo vod, strukturu i produktivnost' biologicheskih soobshchestv [Anthropogenic eutrophication of the main river ecosystems of Belarus and its impact on water quality, structure and productivity of biological communities]. Materialy VIII Mezhdunarodnoj nauchno-prakticheskoj konferencii "Problemy razvitiya rybnogo hozyajstva na vnutrennih vodoemah $v$ usloviyah perekhoda k rynochnym otnosheniyam". In: Konchits, V.V. (ed.), Proceedings of the International Scientific and Practical Conference "Problems of fisheries in inland reservoirs in the conditions of transition to market relations". Minsk, 352-357. [In Russian].

Bartoli, M., Zilius, M., Bresciani, M., Vaiciute, D., Vybernaite-Lubiene, I., Petkuviene, J., Giordani, G., Daunys, D., Ruginis, T., Benelli, S., Giardino, C., Bukaveckas, P.A., Zemlys, P., Griniene, E., Gasiunaite, Z.R., Lesutiene, J., Pilkaityte, R. Baziukas-Razinkovas, A. 2018. Drivers of Cyanobacterial Blooms in a Hypertrophic Lagoon. Frontiers in Marine Science, https://doi.org/10.3389/fmars.2018.00434

Belykh, O.I., Sorokovikova, E.G., Fedorova, G.A., Kaluzhnaya, O.V., Korneva, E.S., Sakirko, M.V., Sherbakova, T.A. 2011. Presence and genetic diversity of microcystin-producing cyanobacteria (Anabaena and Microcystis) in Lake Kotokel (Russia, Lake Baikal Region). Hydrobiologia 671, 241-252.

Belykh, O.I., Dmitrieva, O.A., Gladkikh, A.S., Sorokovikova, E.G. 2013. Identification of Toxigenic Cyanobacteria of the Genus Microcystis in the Curonian Lagoon (Baltic Sea). Oceanology 53 (1), 71-79.

Bernard, C., Ballot, A., Thomazeau, S., Maloufi, S., Furey, A., Mankiewicz-Boczek, J., Pawlik-Skowronska, B., Capelli, C., Salmaso, N. 2017. Appendix 2. Cyanobacteria associated with the production of cyanotoxins. In: Meriluoto, J., Spoof, L., Codd, G.A. (eds). Handbook on cyanobacterial monitoring and cyanotoxin analysis. New York: Wiley, 503-527.

Bilous, O., Barinova, S., Klochenko, P. 2014. The role of phytoplankton in the ecological assessment of the Southern Bug River middle reaches (Ukraine). Fundamental Applied Limnology 184 (4), 277-295.

Bresciani, M., Giardino, C., Stroppiana, D., Pilkaityte, R., Zilius, M., Bartoli, M., Razinkovas, A. 2012. Retrospective analysis of spatial and temporal variability of chlorophyll-a in the Curonian Lagoon. Journal of Coastal Conservation 16 (4), 511-519.

Bresciani, M., Adamo, M., De Carolis, G., Matta, E., Pasquariello, G., Vaiciute, D., Giardino, C. 2014. Monitoring blooms and surface accumulation of cyanobacteria in the Curonian Lagoon by combining MERIS and ASAR data. Remote Sensing of Environment 146, 124-135.

Cole, J., Prairie, Y.T., Caraco, N., McDowell, W.H., Tranvil, L., Striegl, R.G., Duarte, C.M., Kortelainen, P., Downing, J.A., Middelburg, J.J., Melack, J. 2007. Plumbing the global carbon cycle: Integrating inland waters into the terrestrial carbon budget. Ecosystems 10 (1), 171-184. 
Dokulil, M.T. 2014. Potamoplankton and primary productivity in the River Danube. Hydrobiologia 729, 209227.

EC-European Community. 2000. Directive 2000/60/EC of the European Parliament and of the Council of 23 October 2000 establishing a framework for Community action in the field of water. Official Journal of the European Union L 327, 1-72.

Ezhova, E.E., Lange, E.K., Russkikh, Ya.V., Zhakovskaya, Z.A., Chernova, E.N. Harmful algae blooms in the Curonian Lagoon of the Baltic Sea in 2008-2011. 2012. Problemy izucheniya $i$ okhrany prirodnogo $i$ kul'turnogo naslediya natsional'nogo parka «Kurshskaya kosa» [Problems of Study and Protection of Natural and Cultural Heritage of the Curonian Spit National Park: Scientific Articles Collection] 8, 81-95.

Gaevsky, N.A., Kolmakov, V.I., Belykh, O.I., Tikhonova, I.V., Joung, Y., Ahn, T.-S., Nabatova, V.A., Gladkikh, A.S. 2011. Ecological development and genetic diversity of Microcystis aeruginosa from artificial reservoir in Russia. Journal of Microbiology 49 (5), 714-720.

Gkelis, S., Zaoutsos, N. 2014. Cyanotoxin occurrence and potentially toxin producing cyanobacteria in freshwaters of Greece: A multi-disciplinary approach. Toxicon 78, 1-9.

Gladyshev, M.I., Kolmakova, O.V., Tolomeev, A.P., Anishchenko, O.V., Makhutova, O.N., Kolmakova, A.A., Kravchuk, E.S., Glushchenko, L.A., Kolmakov, V.I., Sushchik, N.N. 2015. Differences in organic matter and bacterioplankton between sections of the largest Arctic river: Mosaic or continuum? Limnology and Oceanography 60 (4), 1314-1331.

Hall, T.A. 1999. BioEdit: A user-friendly biological sequence alignment editor and analysis program for Window 95/98/NT. Nucleic Acids Symposium Series 41, 95-98.

HELCOM. 2007. HELCOM Baltic Sea Action Plan. HELCOM Ministerial meeting. Krakow, Poland, 15 November 2007, 1-101.

HELCOM. 2009. Eutrophication in the Baltic Sea - an integrated thematic assessment of the effects of nutrient enrichment in the Baltic Sea region. Baltic Sea Environment Proceedings 115B, 1-148.

HELCOM. 2013. Climate change in the Baltic Sea Area: HELCOM thematic assessment in 2013. Baltic Sea Environment Proceedings 137, 1-66.

Hillebrand, H., Durselen, C.-D., Kirschtel, D. Pollingher, U., Zohary, T. 1999. Biovolume calculation for pelagic and benthic microalgae. Journal of Phycology $35,403-424$.

Jungblut, A.-D., Neilan, A.B. 2006. Molecular identification and evolution of the cyclic peptide hepatotoxins, microcystin and nodularin, synthetase genes in three orders of cyanobacteria. Archives of Microbiology 185, 107-114.

Kaneko, T., Nakajima, N., Okamoto, S., Suzuki, I., Tanabe, Y., Tamaoki, M., Nakamura, Y., Kasai, F., Watanabe, A., Kawashima, K., Kishida, Y., Ono, A.,
Shimizu, Y., Takahashi, C., Minami, C., Fujishiro, T., Kohara, M., Katoh, M., Nakazaki, N., Nakayama, S., Yamada, M., Tabata, S., Watanabe, M. 2007. Complete genomic structure of the bloom-forming toxic cyanobacterium Microcystis aeruginosa NIES-843. DNA Research 14, 247-256.

Kiselev, I.A. 1969. Plankton morej i kontinental'nyh vodoemov [Plankton of seas and continental water bodies]. Leningrad, Nauka, 660 pp. [In Russian].

Krevs, A., Koreiviene, J., Paskauskas, R., Sulijiene, R. 2007. Phytoplankton production and community respiration in different zones of the Curonian Lagoon during the midsummer vegetation period. Transitional Waters Bulletin 1 (1), 17-26.

Kumar, S., Stecher, G., Tamura, K. 2016. MEGA7: molecular Evolutionary Genetics Analysis version 7.0 for bigger datasets. Molecular Biology and Evolution 33 (7), 1870-1874.

Lampert, W., Sommer, U. 2007. Limnoecology: The Ecology of Lakes and Stream, $2^{\text {nd }}$ edition. Oxford: Oxford University Press, 324 pp.

Lange, E.K. 2013. Fitoplanktonnyj kompleks rossijskoj chasti Kurshskogo zaliva (2001-2007) [Phytoplankton complex in the Russian part of the Curonian Lagoon (2001-2007)]. Izvestija KGTU 28, 87-94. [In Russian].

Lange, E.K., Makushenko, M.E. 2018. Sezonnye izmeneniya pokazatelej fitoplanktona i termicheskogo rezhima reki Neman do vvoda v ekspluataciyu Baltijskoj AES [Seasonal changes of phytoplankton indicators and thermal regime of Neman River before putting into operation the Baltic NPP]. Regional'naya ekologiya [Regional Ecology] 51 (1), 67-78. [In Russian].

Lange, E.K, Ezhova, E.E., Russkikh, Y.A.V., Zhakovskaya, Z.A., Chernova, E.N. 2012. Vredonosnye cveteniya mikrovodoroslej v Kurshskom zalive Baltijskogo morya v 2008-2011 godah [Harmful algae blooms in the Curonian Lagoon of the Baltic Sea in 20082011]. Problemy izucheniya $i$ okhrany prirodnogo $i$ kul'turnogo naslediya natsional'nogo parka Kurshskaya kosa [Problems of Study and Protection of Natural and Cultural Heritage of the Curonian Spit National Park: Scientific Articles Collection] 8, 81-95.

Malfanov, I.L., Vakhrusheva, S.A., Trenina, N.E. 2017. Ocenka sostoyaniya Kurshskogo zaliva na osnovanii analiza soderzhaniya form azota i fosfora v 2013-2017 godah [Assessment of the Curonian Lagoon state based on the analysis of nitrogen and phosphorus forms in 2013-2017]. Trudy Atlant NIRO. New series 1 (4), 4655. [In Russian].

Mikheyeva, T.M. 1989. Metody kolichestvennoj ocenki nanofitoplanktona (obzor) [Methods of quantitative enumeration of the nanophytoplankton (review)]. $\mathrm{Hy}$ drobiological Journal 25, 3-21. [In Russian].

Mikheyeva, T.M. 1999. Al'goflora Belarusi. Taksonomicheskij katalog [Algaeflora of Belarus. Taxonomic catalogue]. Minsk: Publishing House, 396 pp. [In Russian]. 
Mikheyeva, T.M., Belykh, O.I., Sorokovikova, E.G., Gladkikh, A.S., Luk'yanova, E.V., Potapov, S.A., Tikhonova, I.V., Fedorova, G.A., Korneva, E.S., Kuzmin, A.V. 2012. Detection of microcystin producing cyanobacteria in the Svisloch River, Belarus. Baltic Coastal Zone 16, 131-146.

Mikheyeva, T.M., Adamovich, B.V., Zhukova, T.V., Savich, I.V., Belykh, O.I., Sorokovikova, E.G., Kuz'min, A.V., Fedorova, G.A., Kovalevskaya, R.Z., Selivonchik, I.N., Dubko, N.V., Luk'yanova, E.V. 2018a. Phytoplankton of Lake Bol'shie Shvakshty (Belarus) during the Shift of the Ecosystem from a Macrophyte-Weakly Eutrophic to a Phytoplankton-Hypereutrophic State. Contemporary Problems of Ecology 11 (6), 563-575.

Mikheyeva, T.M., Mitrakhovich, P.A., Belykh, O.I., Sorokovikova, Ye.G., Samoylenko, V.M., Kovalevskaya, R.Z., Dubko, N.V., Lukyanova, Ye.V., Kuzmin, A.V., Fedorova, G.A., Kartashevich, Z.K. 2018b. Phytoplankton as the Indicator of Changes in the Trophic Status and Water Quality of Lake Kroman Subjected to Anthropogenic Load. Hydrobiological Journal 54 (6), 64-77. [In Russian].

Nishizawa, T., Asayasma, M., Fujii, K., Harada, K., Shirai, M. 1999. Genetic analysis of the peptide synthetase genes for a cyclic heptapeptidemicrocystin in Microcystis spp. Journal of Biochemistry 126, 520-529.

O’Neil, J.M., Davis, T.W., Burford, M.A., Gobler, C.J. 2012. The rise of harmful cyanobacteria blooms: The potential roles of eutrophication and climate change. Harmful Algae 14, 313-334.

Paerl, H.W. 2016. Controlling cyanobacteria harmful blooms in freshwater ecosystems. Microbial Biotechnology 10 (5), 1106-1110.

Paldaviciene, A., Mazur-Marzec, H., Razinkovas, A. 2009. Toxic cyanobacteria blooms in the Lithuanian part of the Curonian Lagoon. Oceanologia 51 (2), 203-216.

Pashkou, G.P., Kalenda, L.V., Zhukouskaya, T.I., Lopuh, P.S., Pirozhnik, I.I., Ulasau, B.P., Yakushka, V.P. (eds). 2007. Blakitny skarb belarusi [Blue treasure of Belarus]. Minsk: BelEn, 480 pp. [In Belarusian].

Pliuta, M.V., Rizevsky, V.K., Novik, I.V. 2007. Kumzhevye vodotoki Belarusi i sostoyanie ih nerestovovyrostnyh ugodij [Brook trout channels in Belarus and the state of their spawning and nursery areas]. Voprosy rybnogo hozyastva Belarusi [Fish industry issues in Belarus] 23, 192-202. [In Russian].

Prosyanik, L.V., Astapovich, I.T., Kutsko, L.A. 1996. Fitoplankton i pervichnaya produkciya reki Neman [Phytoplankton and Primary Production of the Neman River]. Voprosy rybnogo hozyastva Belarusi [Fish industry issues in Belarus] 14, 162-168. [In Russian].

Rantala, A., Fewer, D.P., Hisbergues, M., Rouhiainen, L., Vaitomaa, J., Börner, T., Sivonen, K. 2004. Phylogenetic evidence for the early evolution of microcystin synthesis. PNAS 101, 568-573.

Rekolainen, S., Mitikka, S., Vuorenmaa, J., Johansson, M. 2005. Rapid decline of dissolved nitrogen in Finnish lakes. Journal of Hydrology 304, 94-102.
Rhee, J.-S., Dahms, H.-U., Choi B.-S., Lee J.-S., Choi I.-Y. 2012. Identification and analysis of whole microcystin synthetase genes from two Korean strains of the cyanobacterium Microcystis aeruginosa. Genes \& Genomics 34, 435-439.

Schindler, D.W. 2006. Recent advances in the understanding and management of eutrophication. Limnology and Oceanography 51, 356-363.

Schmidt-Ries, H. 1940. Untersuchungen zur Kenntnis des Pelagiales eines Strandgewässers (Kurisches Haff). Zeitschrift für Fischerei und deren Hilfswissenschaften 37 (2), 138-321.

Semenov, A.D. (ed.) 1977. Rukovodstvo po himicheskomu analizu poverhnostnyh vod sushi [Guide to the chemical analysis of the continental surface waters]. Leningrad: Gidrometeoizdat, 541 pp. [In Russian].

Sivonen, K., Jones, G. 1999. Cyanobacterial Toxins. In: Chorus, I., Bartram, J. (eds). Toxic Cyanobacteria in Water: A Guide to Public Health Significance, Monitoring and Management. London: The World Health Organization, E \& FN Spoon, 41-111.

Spänhoff, B., Dimmer, R., Friese, H., Harnapp, S., Herbst, F., Jenemann, K., Mickel, A., Rohde, S., Schönherr, M., Ziegler, K., Kuhn, K., Müller, U. 2012. Ecological Status of Rivers and Streams in Saxony (Germany) According to the Water Framework Directive and Prospects of Improvement. Water 4 (4), 887-904.

Šulčius, S., Pilkaitytė, R., Mazur-Marzec, H., Kasperovičienè, J., Ezhova, E., Błaszczyk, A., Paškauskas, R. 2015. Increased risk of exposure to microcystins in the scum of the filamentous cyanobacterium Aphanizomenon flosaquae accumulated on the western shoreline of the Curonian Lagoon. Marine Pollution Bulletin 99, 264-270.

Taylor, W.D., Wee, J.L. Wetzel, R.G. 1986. A Modification of the Utermöhl Sedimentation Technique for Improved Identification and Cell Enumeration of Diatoms and Silica-Scaled Chrysophyceae. Transactions of the American Microscopical Society 105 (1), 68-72.

Validation of investments in the nuclear power plant construction in the Republic of Belarus. Book 11. 2010. Environmental impact assessment. 1588-ПЗ-ОИ4. Part 8. EIA Report. Part 8.3. NPP environmental impact assessment explanatory note. http://www.belaes.by/images/Part8.3.pdf. Accessed 26.07.2019.

Vannote, R.L., Minshall, G.W., Cummins, K.W., Sedell, J.R., Cushin, C.E. 1980. The river continuum concept. Canadian Journal of Fisheries and Aquatic Sciences 37, 130-137.

Vybernaite-Lubiene, I., Zilius, M., Saltyte-Vaisiauske, L., Bartoli, M. 2018. Recent Trends (2012-2016) of N, $\mathrm{Si}$, and P Export from the Nemunas River Watershed: Loads, Unbalanced Stoichiometry, and Threats for Downstream Aquatic Ecosystems. Water 10, 1178. doi: 10.3390/w10091178

Wetzel, R.G. 2001. Limnology. Lake and river ecosystems ( $\left.3^{\text {rd }} \mathrm{ed}\right)$. New York: Academic, $1006 \mathrm{pp}$.

Wetzel, R.G., Likens, G.E. 2000. Limnological analysis ( $3^{\text {rd }}$ ed). New York: Springer-Verlag, 429 pp. 